\title{
Knowledge and Usage of Flipped Classroom Instructional Strategy: The Views of Ghanaian Teachers
}

\author{
Rita Yeboah ${ }^{1}$, Ernest Ampadu ${ }^{1}$, Doreen Ahwireng ${ }^{2}$ \& Abraham Okrah ${ }^{1}$ \\ ${ }^{1}$ Department of Teacher Education, University of Ghana, Accra, Ghana \\ ${ }^{2}$ Department of Educational Studies and Leadership, University of Ghana, Accra, Ghana \\ Correspondence: Rita Yeboah, Department of Teacher Education, University of Ghana, Accra, Ghana. E-mail: \\ riyeboah@ug.edu.gh
}

Received: January 20, 2020 Accepted: March 27, 2020 Online Published: April 6, 2020

doi:10.5539/jel.v9n3p57

URL: https://doi.org/10.5539/jel.v9n3p57

\begin{abstract}
This study was designed to examine Ghanaian teachers' knowledge and usage of the flipped classroom instructional strategy. A survey of 109 teachers who pursued a master's degree in education during the 2018/2019 academic year was used for the study. The instrument used for collecting data was a structured questionnaire. The result of the study was analysed using descriptive statistics (frequency, percentages) and inferential statistics (T-test). The results established that majority of the teachers acknowledged the importance of student-centred instructional strategy like the flipped classroom approach, however, majority of these teachers were of the view that they have not experienced or been introduced to this instructional strategy. It was, therefore, not surprising that most of the teachers attested to the fact that they are not using the flipped classroom instructional strategy. The results from the study also revealed that there was no significant difference between school type (public and private) and teachers' knowledge and usage of the flipped classroom instructional strategy. The results from the study attest to the fact that the flipped classroom instructional strategy has not been conceptualised into the Ghanaian classroom. The researchers, therefore, recommend that there is the need for professional development training for teachers on the use of the flipped classroom instructional strategy and sensitisation workshop for students on the use of the flipped classroom instructional strategy and its relevance.
\end{abstract}

Keywords: flipped classroom, instructional strategies, Ghanaian teachers, knowledge and usage

\section{Introduction}

The flipped classroom model is a new and an innovative instructional model, where content presentation and traditional activities normally done in the classroom are given to students as homework, and traditional homework activities become classroom activities (Bergmann \& Sams, 2014). In the flipped classroom, the teacher becomes a facilitator who helps students to actively engage with lesson contents instead of merely presenting lesson contents to students. Teachers involve learners in discussions, problem-solving and hands-on activities (Akçayır \& Akçayır, 2018). The flipped classroom model has been implemented in schools and universities around the world in disciplines such as Mathematics, Social Sciences and Humanities (Hao, 2016). Research findings on the implementation of the flipped classroom model show improved learning experiences and performance of students. In addition to this, the model enhances student satisfaction, confidence, teamwork, engagement, and motivation; promotes creativity, increases problem-solving skills of learners and makes the learning process more fun in comparison to the traditional method of teaching and learning (Bergmann \& Sams, 2014; Akçayır \& Akçayır, 2018; Awidia \& Paynterb, 2019). This nature of the flipped model ensures that when it is implemented, the 21 st-century skills of communication, innovation, creativity and collaboration are exhibited in the learning process. Thus, this instructional strategy is very needful and relevant for teaching and learning. In this regard, this study sought to find out Ghanaian teachers' knowledge and usage of the flipped classroom model. The following research questions, therefore, guide the present study;

- What characterises teachers' knowledge of a flipped classroom as an instructional strategy?

- What is the difference (if any) between school type and teacher's knowledge of flipped classroom as an instructional strategy?

- To what extent do teachers use flipped classroom instructional strategy? 


\section{Literature Review}

\subsection{The Flipped Classroom Model}

The flipped learning approach was identified from exploring with hybrid or blended learning and problem-based learning, which engages students actively in the learning process through the application of technology (Educause, 2012; Arnold-Garza, 2014). The flipped classroom or learning is a concept where the direct instruction by a teacher in the classroom and homework elements of a subject or course are reversed (Educause, 2012; Bergmann \& Sams, 2014; Szparagowski, 2014; Du, Fu, \& Wang, 2014; Karlsson \& Janson, 2016). This means that the exercise students normally perform at home as homework is done in the classroom in the form of active exercises, group projects and discussions and the direct instruction given by teachers during classroom hours is given to students as homework in the form of videos and readings before class. Such a video or reading can be created by the teacher or taken from an online repository. Such videos are helpful as teachers infuse "visual representations such as interactive graphs, videos, or photos of important historical events" (Educause, 2012; Goodwin \& Miller, 2013, p. 78; Bergmann \& Sams, 2014; Szparagowski, 2014; Du, Fu, \& Wang, 2014; Karlsson \& Janson, 2016). Flipped learning does not eliminate homework because students administer homework activities in the classroom (Elian \& Hamaidi, 2018). In a typical flip classroom, after students have reviewed learning materials at home, they attend class prepared to apply what they have learnt at home. The teacher starts the classroom lesson by evaluating students' understanding and revising what has been learnt at home. This is preceded by the teacher giving students activities and group problem-based projects to perform in class on what was studied at home rather than students passively listening to a teacher's explanation in the classroom (Asiksoy \& Ozdamli, 2016). According to Üğüten and Balci (2017), the four pillars of flipped learning are flexible environment, learning culture, intentional content and professional educators. Flexible environment: this is important for both teachers and students in flip learning. Here, teachers can prepare videos and readings whenever and wherever they want, likewise, students can access videos and readings without any time and place limitation. Learning culture: "in flipped classrooms, there is a shift from teacher-centred classrooms to learner-centred ones in which students are no more passive. Instead, they take active roles in their learning procedure and constructing knowledge" (Üğ̈̈ten \& Balci, 2017, p. 257). Intentional content: in the flipped learning approach, the content of videos and readings are determined by the teacher according to the needs and interests of the students. Intentional content gives direction to what the teacher will be teaching and the resources that must be sent to students to learn. Professional educator: the teacher's role in a flipped classroom is not the same as that of a traditional one. In the flipped classroom, teachers are not information givers, but rather they act as facilitators or coaches for students to construct their own knowledge. Professional educators are reflective and get in touch with each other to improve themselves (Chang, 2016).

\subsection{Teachers' Knowledge of the Flipped Classroom Instructional Strategy}

New technologies and easy access to them are rapidly changing teachers' instructional strategies and students' learning habits and expectations of schools. Recently, a growing number of teachers have flipped their traditional lecture classrooms and implemented the flipped classroom instructional model to adapt to the changing needs of students in this $21 \mathrm{st}^{-}$century (Hunley, 2016). Concerning the flipped classroom model, a study conducted by Inan, Balakrishnan and Refeque (2019) on teachers' and students' perceptions showed that the participants perceive flipped learning as an innovative and effective instructional process that enhances student learning and improves the skills of both teachers and students. Teachers and students from this study agreed that the flipped classroom model provides more time to focus on the higher level of learning because the model makes it possible for students to come to class having a basic knowledge of the topic to be treated. This, according to the teachers and students, leads to a more fruitful use of class time. These respondents were of the opinion that the flipped classroom model can accomplish its purpose only if students take responsibility for their learning and come to class prepared (Inan, Balakrishnan, \& Refeque, 2019). According to Herried and Schiller (2013), some Science, Technology, Engineering, and Math teachers expressed that the flipped classroom instructional strategy allows more time to spend with students on authentic research and more time to work on scientific lab equipment. Some concerns on the model articulated by these STEM teachers in a case study were as follows:

- Students may resist the implementation of the model because it requires them to be responsible for their learning at home and in the classroom,

- Teachers must be able to design homework activities that are carefully tailored to in-class activities, and

- Creating videos to implement the model requires a considerable amount of time (Herreid \& Schiller, 2013). 


\subsection{Teacher Usage of the Flipped Classroom Instructional Strategy}

Use of flipped classroom is increasingly gaining recognition in disciplines such as health, science, technology, engineering, and mathematics (Betihavas et al., 2016; Huber \& Werner, 2016; Karabulut-Ilgu et al., 2017; Lo, 2018; Presti, 2016; Ramnanan \& Pound, 2017; Seery, 2015). Scholars agree that lecturers deliver lectures before class periods through instructional videos (Bergmann \& Sams, 2008; Snyder et al., 2014) and determine students' understanding through quizzes uploaded on Moodle or Blackboard and at the same time instructors provide feedback online (Mok, 2014; Petrillo, 2016). Instructors use direct classroom contact hours for active learning and problem-solving activities with students (Abeysekera \& Dawson, 2015; Bergmann \& Sams, 2008; Lo, 2018; Spector, 2016). Khanova et al. (2015) explained that before classrooms are flipped, course structures are introduced, and reasons for flipping the classroom are provided to students a week before the commencement of the course.

Similarly, Porcaro, Jackson, McLaughlin, and O’Malley (2016) commented that students are prepared for the flipped classroom before the start of the semester, because, preparation is pivotal to implementing a flipped classroom. During preparation, instructors are interested in students' understanding of the reasons, instructors' expectation of students, advantages, objectives and activities, as well as course logistics involved in flipping the classroom (Al-Zahrani, 2015; Betihavas et al., 2016; Lo, 2018; Gross et al., 2015; Reddan et al., 2016; Gilboy et al., 2015; Khanova et al., 2015a; Porcaro et al., 2016; Gaughan, 2014; Seyedmonir et al., 2014; Al-Zahrani, 2015). Equally, Wang (2016) argued that teachers who intend to implement the flip model must inform parents about how the model operates. Wang (2016) attempted to incorporate mobile learning into his flipped classroom, but some students were not happy and complained that they did not have ample time to use the system to learn because parents restricted them on the use of mobile phones (Wang, 2016). Parents' limited understanding of flipped classroom is evident in the restrictions given to students on the use of mobile phones. To remedy parents' frustration and misunderstanding, Lo (2018) agrees with Wang that schools should inform parents about the flipped classroom instructional approach and seek their consent for the change in the instructional model when necessary. In addition to parents' frustration, students report their inability to ask immediate questions when they engage with the videos that instructors post online (Hotle \& Garrow, 2016; McGivney-Burelle \& Xue, 2013; Schultz, Duffield, Rasmussen, \& Wageman, 2014). Bhagat, Chang and Chang (2016) and Westermann (2014) concur that discussion forums should be created to help students interact with their teachers about lecture videos online. Such interactions will help clarify confusions that students might have.

Further, Westermann (2014) posits that students post their written assignments on discussion forums for peers and instructor to give comments. Mok (2014) reported that he fused multiple-choice and fill-in-the-blank questions with computerised feedback into his pre-class teaching and learning activities online. Similarly, Gaughan (2014) recounted her experience on how she created her first course for a flipped classroom. She sought help from the Information Technology Department to upload her instructional videos online for students to access. For instance, at Vaughan University, regular professional development sessions with information technology specialists were held to equip lecturers on how to flip classrooms. Additionally, school-based professional development training on the use of learning management systems technology, mobile learning, and video production was organised for faculty to enable them to flip classrooms (Miller, 2016; Lo, 2018). Other scholars also recount their experience using an interactive technology like Clickers (Flynn, 2015; Jungic' et al., 2015; Vazquez \& Chiang, 2015) to coalesce students' responses for online quizzes. Seery (2015) reports that students studying chemistry at the university level were enthusiastic about flipped learning. However, Lo and Hew (2017) found that some K-12 students did not like the flipped instructional approach. Similarly, Wang (2016) observed that Asian students are not enthusiastic about self-directed learning. Therefore, through flipped classroom, instructors should emphasise student-centred learning for students to own their learning which is one of the benefits of flipping classrooms (Marcum \& Perry, 2015; Lo, 2018; Van Sickle, 2016).

Goodwin and Miller (2013) observed that some teachers are increasingly incorporating flipped classroom into their teaching and learning by recording and posting lectures online. Two secondary school teachers recorded their lectures using screencasting software and posted them online for students to watch before class. They used class periods for more productive and in-depth interactions and activities to help students understand concepts that appear challenging (Bergmann \& Sams, 2014). Graziano (2017) observed that the number of high school teachers who flipped their classrooms increased from $48 \%$ in 2012 to $78 \%$ in 2014. Herreid and Schiller (2013) reported that out of 15,000 STEM teachers surveyed, 200 teachers used the flipped classroom. Yarbro et al. (2014) observed that faculty at institutions of higher learning are increasingly flipping classrooms. Faculty who flipped classrooms reported, "increased motivation, engagement, and increased reinforcement of concepts" (Graziano, 2017, p. 122). According to the Flipped Learning Network (2012), users of the flipped classroom on 
its social media sky-rocketed from 2,500 teachers in 2011 to 9,000 teachers in 2012.

\section{Methodology}

The purpose of this study was to examine teacher's knowledge and usage of the flipped classroom instructional strategy. A survey design was used to collect data to answer the research questions. The survey included one hundred and nine (109) teachers from the Basic to the Senior High level from both private (31) and public (78) schools in Ghana. The teaching experience of the teachers ranged from one to twenty years. The convenience sampling method was used to select the participants from the cohort of students who pursued a master's degree in education at the University of Ghana during the 2018/2019 academic year. The survey instrument had three sections: student-centred first section-was used to elicit teachers' background data; the second section was used to collect data regarding their knowledge about the flipped classroom instructional strategy and the last section had questions eliciting information about teacher's usage of the flipped classroom instructional strategy. The reliability of the instrument was measured using alpha Cronbach reliability, and coefficient of 0.752 was obtained. With this reliability coefficient, it was clear that the instrument was reliable, as suggested by Hulin, Netemeyer, and Cudeck (2001). The analysis of the data was done using the Statistical Package for Social Science (SPSS) where descriptive statistics such as percentages and frequencies were used to measure the levels of agreement in relation to the various scales. In addition to this, a T-Test was conducted to examine if there is any difference between teachers' knowledge of flipped classroom and school type (that is public and private school). Three primary ethical considerations were adhered to during the research process: anonymity, confidentiality and informed consent. The teachers were made aware of the purpose of the study and were guaranteed that their identities would not be revealed in any part of the report. Besides, they were assured that their responses will be kept confidential and will only be used for the purpose for which it was collected.

\section{Results}

\subsection{Characteristics of Teachers' Knowledge of a Flipped Classroom as an Instructional Strategy}

To find answers to the first research question, the participants were asked to indicate the extent to which they agree to eight items using a 5-point Likert scale: Strongly Agree (SA), Agree (A), Undecided (U), Disagree (D) and Strongly Disagree (SD). The result is depicted in Table 1.

Table 1. Teachers' knowledge of a flipped classroom instructional strategy

\begin{tabular}{|c|c|c|c|c|c|}
\hline Statements & SA & $\mathbf{A}$ & $\mathbf{U}$ & D & SD \\
\hline \multirow{2}{*}{ I was taught flipped classroom instructional strategy in school } & 2 & 12 & 31 & 23 & 41 \\
\hline & $1.8 \%$ & $11 \%$ & $28.4 \%$ & $21.1 \%$ & $37.6 \%$ \\
\hline \multirow[t]{2}{*}{ I got to know flipped classroom instructional strategy through a friend } & 7 & 11 & 25 & 22 & 44 \\
\hline & $6.4 \%$ & $10.1 \%$ & $22.9 \%$ & $20.1 \%$ & $40.4 \%$ \\
\hline \multirow[t]{2}{*}{ Flipped classroom instructional strategy is teacher-centred } & 5 & 16 & 21 & 28 & 39 \\
\hline & $4.6 \%$ & $14.7 \%$ & $19.3 \%$ & $25.7 \%$ & $35.8 \%$ \\
\hline \multirow[t]{2}{*}{ Flipped classroom instructional strategy is leaner centred } & 29 & 41 & 20 & 12 & 7 \\
\hline & $26.6 \%$ & $37.6 \%$ & $18.3 \%$ & $11.0 \%$ & $6.4 \%$ \\
\hline \multirow[t]{2}{*}{ Flipped classroom instructional strategy is about collaborative learning } & 36 & 41 & 21 & 6 & 5 \\
\hline & $33 \%$ & $37.6 \%$ & $19.3 \%$ & $5.5 \%$ & $4.6 \%$ \\
\hline \multirow{2}{*}{$\begin{array}{l}\text { In a flipped classroom, instructional strategy content relates to the real-world } \\
\text { situation }\end{array}$} & 36 & 42 & 22 & 6 & 3 \\
\hline & $33 \%$ & $38.5 \%$ & $20.2 \%$ & $5.5 \%$ & $2.8 \%$ \\
\hline \multirow{2}{*}{$\begin{array}{l}\text { Teaching and learning in the classroom and home by activating the role of } \\
\text { modern technological tools in preparing and presenting lessons is basically a } \\
\text { flipped, instructional model. }\end{array}$} & 34 & 35 & 19 & 10 & 11 \\
\hline & $31.2 \%$ & $32.1 \%$ & $17.4 \%$ & $9.2 \%$ & $10.1 \%$ \\
\hline
\end{tabular}

From Table 1, teachers' knowledge about the flipped classroom as an instructional strategy is a mixed bag as there exist variations in the responses. For example, regarding the first two statements, $58.7 \%$ and $60.5 \%$ of the respondents ascribed negatively to statements 1 and 2, respectively. This suggests that most of the respondents have neither been taught using the flipped classroom instructional strategy nor heard about it from their colleagues or friends. However, it is interesting to note that even though most of the respondents have not experienced a flipped classroom instruction by themselves majority of them ascribed positively to the fact that flipped classroom instructional strategy is a learner-centred strategy, and it is all about collaborative learning. In addition to this, more than half of the respondents were of the view that they think teaching and learning in the classroom and home by activating the role of modern technological tools in preparing and presenting lessons is 
basically flipped, instructional model. That is, even though the majority of these teachers have not experienced flipped classroom instruction themselves, they are aware of the fact that this instructional approach is not teacher-centred. This is evidenced in their responses to items 3 and 4 , where $61.5 \%$ indicated that this strategy is not a teacher-centred strategy and $64.2 \%$ indicating that it is a student-centred approach.

\subsection{School Type and Teacher's Knowledge of Flipped Classroom as an Instructional Strategy}

The purpose of the second research question was to examine if there is any relationship between the type of school (public or private) and teachers' knowledge of flipped classroom instructional strategy. The result is depicted in Table 2.

Table 2. Relationship between school type and teacher's knowledge of flipped classroom

\begin{tabular}{lllllllll}
\hline & & F & Sig. & t & df & $\begin{array}{l}\text { Sig. } \\
\text { (2-tailed) }\end{array}$ & $\begin{array}{l}\text { Mean } \\
\text { Difference }\end{array}$ & $\begin{array}{l}\text { Std. Error } \\
\text { Difference }\end{array}$ \\
\hline $\begin{array}{l}\text { School Type and } \\
\text { knowledge of flipped } \\
\text { classroom instructional }\end{array}$ & $\begin{array}{l}\text { Equal variances } \\
\text { assumed }\end{array}$ & 1.603 & 0.41 & 0.18 & 106 & 0.497 & 30.8 & 0.25 \\
$\begin{array}{l}\text { Equal variances not } \\
\text { assumed }\end{array}$ & & & 0.19 & 53.8 & 0.493 & 0.1 & 0.25 \\
\hline
\end{tabular}

There was no significant difference in the knowledge of public and private school teachers $\mathrm{t}(106)=0.18, \mathrm{P}=$ 0.49. These results suggest that school difference does not influence the knowledge of teachers regarding flipped classroom as an instructional strategy. Teachers in private schools $(\mathrm{N}=31)$ ascribed more positively by indicating that they have some knowledge in or have experienced flipped classroom instructional strategy as compared to their counterparts from public schools $(\mathrm{N}=78)$.

\subsection{Teachers' Usage of Flipped Classroom Instructional Strategy}

The third research question aimed at examining teachers' usage of flipped classroom instructional strategy. To find an answer to this question, the participants were asked to indicate the extent to which they agree to eight items using a 5-point Likert scale; Strongly Agree (SA), Agree (A), Undecided (U), Disagree (D) and Strongly Disagree (SD).

Table 3. Teachers' usage of a flipped classroom instructional strategy

\begin{tabular}{|c|c|c|c|c|c|}
\hline Statements & $\mathbf{S A}$ & $\mathbf{A}$ & $\mathbf{U}$ & D & SD \\
\hline \multirow[t]{2}{*}{ I used the flipped classroom instructional strategy when I was in school. } & 4 & 9 & 25 & 21 & 50 \\
\hline & $3.7 \%$ & $8.3 \%$ & $22.9 \%$ & $19.3 \%$ & $45.9 \%$ \\
\hline \multirow[t]{2}{*}{ The size of my class allows me to use the flipped instructional strategy. } & 5 & 14 & 26 & 30 & 34 \\
\hline & $4.6 \%$ & $12.8 \%$ & $23.9 \%$ & $27.5 \%$ & $31.2 \%$ \\
\hline \multirow[t]{2}{*}{ I know how to use the flipped instructional strategy in teaching. } & 11 & 22 & 37 & 18 & 21 \\
\hline & $10.1 \%$ & $20.2 \%$ & $33.9 \%$ & $16.5 \%$ & $19.3 \%$ \\
\hline I use this method only with some specific subjects, e.g. English. & $9.2 \%$ & $12.8 \%$ & $30.3 \%$ & $16.5 \%$ & $31.2 \%$ \\
\hline \multirow{2}{*}{$\begin{array}{l}\text { The environment of the class is very conducive for the use of the flipped classroom } \\
\text { instructional strategy }\end{array}$} & 12 & 15 & 21 & 35 & 26 \\
\hline & $11 \%$ & $13.8 \%$ & $19.3 \%$ & $32.1 \%$ & $23.9 \%$ \\
\hline \multirow[t]{2}{*}{ I use flipped classroom instructional strategies in teaching all subjects. } & 3 & 9 & 16 & 34 & 47 \\
\hline & $2.8 \%$ & $8.3 \%$ & $14.7 \%$ & $31.2 \%$ & $43.1 \%$ \\
\hline I never knew anything about the usage of flipped classroom instructional strategy & 6 & 10 & 27 & 36 & 30 \\
\hline \multirow{2}{*}{$\begin{array}{l}\text { In the usage of the flipped classroom model, content is delivered before class time, } \\
\text { and lecture time become forums for discussion, integration, and application of that } \\
\text { content. }\end{array}$} & 24 & 21 & 28 & 20 & 16 \\
\hline & $22.0 \%$ & $19.3 \%$ & $25.7 \%$ & $18.3 \%$ & $14.7 \%$ \\
\hline
\end{tabular}

Table 3 shows that the usage of a flipped classroom instructional strategy has not been conceptualised in the Ghanaian classroom. This is evident from the results where over $60 \%$ of the teachers disagreed to the statement "I used flipped classroom instructional strategy when I was in school". Also, 74\% of the participants indicated that they do not use flipped classroom instructional strategy in teaching all subjects. Further, $30 \%$ of the teachers indicated they knew how to implement the flipped classroom model. Still, over 58 and 55 per cent of the teachers respectively reported their classroom environment and class sizes do not allow them to implement this model. 
Majority of the teachers also indicated that they had not been taught how to implement the flipped strategy. But over $40 \%$ of the teachers responded positively to the statement "In the usage of flipped classroom model, content is delivered before class time, and lecture time becomes forums for discussion, integration, and application of that content" which is consistent with the results on teachers' knowledge of the flipped classroom strategy.

\section{Discussion}

Teachers' use of creative approaches in teaching can be understood by examining the knowledge and usage of these innovative methods. The purpose of this study was to investigate teachers' knowledge and usage of a flipped classroom as an instructional strategy. From research question one, it was deduced that although the majority of the teachers were not introduced to the flipped model as part of their training and had not also experienced it from friends, they were aware of the fact that the model is student-centred. This knowledge by the teachers may have been derived from their own readings and research, which is a good practice that must be encouraged among practising teachers. As indicated by Ügüten and Balci (2017), one of the four pillars of the flipped model is a shift from teacher-centredness to learner centred classrooms. In such classes, learners take an active role in constructing their own knowledge with the teacher only acting as a facilitator of the process. Again, more than half of the respondents identified with the fact that the flipped classroom instructional strategy allows collaborative learning of real-life situations. In line with the literature, in the implementation of the flip model, the in-class activities are characterised by collaborative activities among students to make meaning of instruction contents (Educause, 2012; Goodwin \& Miller, 2013; Bergmann \& Sams, 2014; Szparagowski, 2014; Du, Fu, \& Wang, 2014; Karlsson \& Janson, 2016; Asiksoy \& Ozdamli, 2016). Further, majority of the teachers also acknowledged that in implementing the flipped model, technological tools are used to present homework and in-class activities. Gaughan (2014), Miller (2016) and Lo (2018) all make mention of technological tools for implementing the flipped strategy. It is worth noting that although the majority of the participants in this study have not experienced or have not been taught using this instructional strategy, they showed some level of enthusiasm that the flipped classroom instructional strategy is suitable for both teachers and students. With regards to the difference in knowledge of the flipped model between private and public-school teachers at the Basic and Senior High levels, although not significant, private school teachers indicated having more knowledge of the model than public school teachers. This can be due to the fact that, in Ghana, private schools mostly use and embrace more innovative teaching and learning strategies than public schools. This situation is so because, in Ghana, most private schools are provided with relevant materials to enhance the teaching and learning process than public schools.

Contrary to the findings from Graziano's (2017) study, the findings from this study established that the use of the flipped classroom instructional strategy is not something that has been conceptualised into the Ghanaian classroom. Although the majority of the teachers who took part in the study acknowledged they have some knowledge on how the flipped model operates, and that it helps promote students' understanding and participation, not all the teachers have used or known how to use this instructional strategy in their classrooms. The findings from this study, therefore, support Miller's (2016) and Lo's (2018) argument that there is the need for school-based professional development training on the use of learning management systems technology, mobile learning, and video production for teachers to enable them to flip classrooms. Also, apart from the training for teachers, the usage of the flipped instructional practice may not yield the expected results if the needed technological equipment are not available for use by both students and teachers. Likewise, to avoid the experiences of Wang (2016) and Lo and Hew (2017), students will need some sensitisation workshops on the importance and relevance of the flipped classroom instructional strategy (Porcaro et al., 2016).

\section{Conclusion}

Improving students' learning experiences and performance has become an issue of concern across most classrooms and school contexts. One of the ways of improving students' learning experiences and performance is the use of innovative and creative approaches that incorporate technology in the teaching and learning process. As highlighted above, one of such creative approaches is the use of the flipped classroom instructional strategy. Review of the literature has shown that the use of this approach helps in producing students who are critical thinkers and are able to transfer their acquired knowledge in solving real-life problems. The findings from the present study show that participants, despite acknowledging having knowledge about the flipped classroom strategy, majority of them have not been taught how to use the approach and hence have not used it in their classrooms. Therefore, in our quest to train students who can be competitive in the 21 st-century world, Ghana Education Service in collaboration with Colleges of Education should train practising teachers and student-teachers how to implement modern instructional strategies such as the flipped classroom model. 


\section{References}

Abeysekera, L., \& Dawson, P. (2015). Motivation and cognitive load in the flipped classroom: Definition, rationale and a call for research. Higher Education Research \& Development, 34(1), 1-14. https://doi.org/10.1080/07294360.2014.934336

Akçayır, G., \& Akçayır, M. (2018). The flipped classroom: A review of its advantages and challenges. Computers \& Education, 126, 334-345. https://doi.org/10.1016/j.compedu.2018.07.021

Al-Zahrani, A. M. (2015). From passive to active: The impact of the flipped classroom through social learning platforms on higher education students' creative thinking. British Journal of Educational Technology, 46(6), 1133-1148. https://doi.org/10.1111/bjet.12353

Arnold-Garza, S. (2014). The flipped classroom teaching model and its use for information literacy instruction. Communications in Information Literacy, 8(1), 7-22. https://doi.org/10.15760/comminfolit.2014.8.1.161

Awidi, I. T., \& Paynter, M. (2019). The impact of a flipped classroom approach on student learning experience. Computers \& Education, 128, 269-283. https://doi.org/10.1016/j.compedu.2018.09.013

Bergmann, J., \& Sams, A. (2008). Remixing chemistry class. Learning and Leading with Technology, 36(4), 24 27. https://doi.org/10.1190/tle27010036.1

Bergmann, J., \& Sams, A. (2014). Flipped learning: Maximizing face time. Learning and Development, 68(2), $28-31$.

Betihavas, V., Bridgman, H., Kornhaber, R., \& Cross, M. (2016). The evidence for 'flipping out': A systematic review of the flipped classroom in nursing education. Nurse Education Today, 38, 15-21. https://doi.org/10.1016/j.nedt.2015.12.010

Bergmann, J., \& Sams, A. (2014). The flipped classroom. CSE, 17(3).

Bhagat, K. K., Chang, C. N., \& Chang, C. Y. (2016). The impact of the flipped classroom on mathematics concept learning in high school. Educational Technology \& Society, 19(3), 134-142.

Chang, S. H. (2016). The marriage of constructivism and flipped learning. Retrieved June 13, 2019, from https://eric.ed.gov/?id=ED565608

Du, S., Fu, Z., \& Wang, Y. (2014). The flipped classroom - advantages and challenges. International Conference on Economic Management and Trade Cooperation. Atlantis Press.

Educause. (2012). Flipped classroom. Retrieved June 13, 2019, from https://library.educause.edu/resources/2012/2/7-things-you-should-know-about-flipped-classrooms

Elian, S. A., \& Hamaidi, D. A. (2018). The effect of using flipped classroom strategy on the academic achievement of fourth grade students in Jordan. International Journal of Emerging Technologies in Learning, 13(2), 110-125. https://doi.org/10.3991/ijet.v13i02.7816

Flipped Learning Network. (2012). Improve student learning and teacher satisfaction with one flip of the classroom.

Flynn, A. B. (2015). Structure and evaluation of flipped chemistry courses: Organic \& spectroscopy, large and small, first to third year, English and French. Chemistry Education Research and Practice, 16(2), 198-211. https://doi.org/10.1039/C4RP00224E

Gaughan, J. E. (2014). The flipped classroom in world history. History Teacher, 47(2), 221-244.

Gilboy, M. B., Heinerichs, S., \& Pazzaglia, G. (2015). Enhancing student engagement using the flipped classroom. Journal of Nutrition Education and Behavior, 47(1), 109-114. https://doi.org/10.1016/j.jneb.2014.08.008

Goodwin, B., \& Miller, K. (2013). Evidence on flipped classrooms is still coming in. Educational Leadership, $70(6), 78-80$.

Graziano, K. J. (2017). Peer teaching in a flipped teacher education classroom. TechTrends, 61(2), 121-129. https://doi.org/10.1007/s11528-016-0077-9

Gross, B., Marinari, M., Hoffman, M., DeSimone, K., \& Burke, P. (2015). Flipped @ SBU: Student satisfaction and the college classroom. Educational Research Quarterly, 39(2), 36-52.

Hao, Y. (2016). Exploring undergraduates' perspectives and flipped learning readiness in their flipped classrooms. Computers in Human Behavior, 59, 82-92. https://doi.org/10.1016/j.chb.2016.01.032 
Herreid, C., \& Schiller, N. (2013). Case studies and the flipped classroom. Journal of College Science Teaching, $42(5), 62-66$.

Hotle, S. L., \& Garrow, L. A. (2016). Effects of the traditional and flipped classrooms on undergraduate student opinions and success. Journal of Professional Issues in Engineering Education and Practice, 142(1), 1-11. https://doi.org/10.1061/(ASCE)EI.1943-5541.0000259

Huber, E., \& Werner, A. (2016). A review of the literature on flipping the STEM classroom: Preliminary findings. In S. Barker, S. Dawson, A. Pardo \& C. Colvin (Eds.), Show me the learning (pp. 267-274). Proceedings ASCILITE 2016 Adelaide.

Hulin, C., Netemeyer, R., \& Cudeck, R. (2001). Can a reliability coefficient be too high? Journal of Consumer Psychology, 10(1), 55-58. https://doi.org/10.1207/S15327663JCP1001\&2_05

Hunley, R. C. (2016). Teacher and Student Perceptions on High School Science Flipped Classrooms: Educational Breakthrough or Media Hype? Electronic Theses and Dissertations. Paper 3052. Retrieved June 13, 2019, from https://dc.etsu.edu/etd/3052

Inan, N. K., Balakrishnan, K., \& Refeque, M. (2019). Flipping perceptions, engagements and realities: A case study. Turkish Online Journal of Distance Education, 20(1), 208-222. https://doi.org/10.17718/tojde.522717

Jungic, V., Kaur, H., Mulholland, J., \& Xin, C. (2015). On flipping the classroom in large first year calculus courses. International Journal of Mathematical Education in Science and Technology, 46(4), 508-520. https://doi.org/10.1080/0020739X.2014.990529

Karabulut - Ilgu, A., Jaramillo Cherrez, N., \& Jahren, C. T. (2018). A systematic review of research on the flipped learning method in engineering education. British Journal of Educational Technology, 49(3), 398-411. https://doi.org/10.1111/bjet.12548

Karlsson, G., \& Janson, S. (2016). The flipped classroom: a model for active student learning (pp. 127-136). From books to MOOCs, Portland Press Limited.

Khanova, J., Roth, M. T., Rodgers, J. E., \& McLaughlin, J. E. (2015b). Student experiences across multiple flipped courses in a single curriculum. Medical Education, 49(10), 1038-1048. https://doi.org/10.1111/medu.12807

Lo, C. K. (2018). Grounding the flipped classroom approach in the foundations of educational technology. Educational Technology Research and Development, 66(3), 793-811. https://doi.org/10.1007/s11423-018-9578-x

Lo, C. K., \& Hew, K. F. (2017). A critical review of flipped classroom challenges in K-12 education: Possible solutions and recommendations for future research. Research and Practice in Technology Enhanced Learning, 12(1), 1-22. https://doi.org/10.1186/s41039-016-0044-2

Marcum, T. M., \& Perry, S. J. (2015). Flips and flops: A new approach to a traditional law course. Journal of Legal Studies Education, 32(2), 255-286. https://doi.org/10.1111/jlse.12028

McGivney-Burelle, J., \& Xue, F. (2013). Flipping calculus. PRIMUS, 23(5), 477-486. https://doi.org/10.1080/10511970.2012.757571

Miller, C. L. (2016). A full flip: One Catholic university's journey with campus-wide flipped instruction. Journal of Catholic Education, 20(1), 56-85. https://doi.org/10.15365/joce.2001032016

Mok, H. N. (2014). Teaching tip: The flipped classroom. Journal of Information Systems Education, 25, 7-11.

Petrillo, J. (2016). On flipping first-semester calculus: A case study. International Journal of Mathematical Education in Science and Technology, 47(4), 573-582. https://doi.org/10.1080/0020739X.2015.1106014

Porcaro, P. A., Jackson, D. E., McLaughlin, P. M., \& O’Malley, C. J. (2016). Curriculum design of a flipped classroom to enhance haematology learning. Journal of Science Education and Technology, 25(3), 345-357. https://doi.org/10.1007/s10956-015-9599-8

Presti, C. R. (2016). The flipped learning approach in nursing education: A literature review. Journal of Nursing Education, 55(5), 252-257. https://doi.org/10.3928/01484834-20160414-03

Ramnanan, C. J., \& Pound, L. D. (2017). Advances in medical education and practice: Student perceptions of the flipped classroom. Advances in Medical Education and Practice, 8, 63-73. https://doi.org/10.2147/AMEP.S109037 
Reddan, G., McNally, B., \& Chipperfield, J. (2016). Flipping the classroom in an undergraduate sports coaching course. International Journal of Sports Science \& Coaching, 11(2), 270-278. https://doi.org/10.1177/1747954116637497

Schultz, D., Duffield, S., Rasmussen, S. C., \& Wageman, J. (2014). Effects of the flipped classroom model on student performance for advanced placement high school chemistry students. Journal of Chemical Education, 91(9), 1334-1339. https://doi.org/10.1021/ed400868x

Seery, M. K. (2015). Flipped learning in higher education chemistry: Emerging trends and potential directions. Chemistry Education Research and Practice, 16(4), 758-768. https://doi.org/10.1039/C5RP00136F

Seyedmonir, B., Barry, K., \& Seyedmonir, M. (2014). Developing a community of practice (CoP) through interdisciplinary research on flipped classrooms. Internet Learning, 3(1), 85-94. https://doi.org/10.18278/il.3.1.7

Snyder, C., Paska, L. M., \& Besozzi, D. (2014). Cast from the past: Using screencasting in the social studies classroom. The Social Studies, 105(6), 310-314. https://doi.org/10.1080/00377996.2014.951472

Spector, J. M. (2016). Foundations of educational technology: Integrative approaches and interdisciplinary perspectives (2nd ed.). New York: Routledge. https://doi.org/10.4324/9781315764269

Szparagowski, R. (2014). Exploring the effectiveness of the flipped classroom. Honors Projects. Retrieved June 13, 2019, from https://scholarworks.bgsu.edu/honorsprojects/127

Üğüten, S. D., \& Balci, Ö. (2017). Flipped learning. Süleyman Demirel Üniversitesi Sosyal Bilimler Enstitüsü Dergisi, 26, 253-265.

Van Sickle, J. (2016). Discrepancies between student perception and achievement of learning outcomes in a flipped classroom. Journal of the Scholarship of Teaching and Learning, 16(2), 29-38. https://doi.org/10.14434/josotl.v16i2.19216

Vazquez, J. J., \& Chiang, E. P. (2015). Flipping out! A case study on how to flip the principles of economics classroom. International Advances in Economic Research, 21, 379-390. https://doi.org/10.1007/s11294-015-9549-5

Wang, Y. H. (2016). Could a mobile-assisted learning system support flipped classrooms for classical Chinese learning? Journal of Computer Assisted Learning, 32, 391-415. https://doi.org/10.1111/jcal.12141

Westermann, E. B. (2014). A half-flipped classroom or an alternative approach? Primary sources and blended learning. Educational Research Quarterly, 38(2), 43-57.

Yarbro, J., Arfstrom, K. M., McKnight, K., \& McKnight, P. (2014). The 2014 extension of the 2013 review of flipped learning. Retrieved June 13, 2019, from http://www.flippedlearning.org $>$ wp-content $>$ uploads $>2016 / 07>$ Extension-of...

\section{Copyrights}

Copyright for this article is retained by the author, with first publication rights granted to the journal.

This is an open-access article distributed under the terms and conditions of the Creative Commons Attribution license (http://creativecommons.org/licenses/by/4.0/). 